\title{
Kineosporia mesophila sp. nov., isolated from surface-sterilized stems of Tripterygium wilfordii
}

\author{
Correspondence \\ Wen-Jun Li \\ wjli@ynu.edu.cn or \\ liact@hotmail.com
}

\author{
Jie Li, ${ }^{1}$ Guo-Zhen Zhao, ${ }^{1}$ Hai-Yu Huang, ${ }^{1}$ Sheng Oin, ${ }^{1}$ Wen-Yong Zhu, ${ }^{1}$ \\ $\mathrm{Li}-\mathrm{Hua} \mathrm{Xu}^{1}$ and Wen-Jun $\mathrm{Li}^{1,2}$
${ }^{1}$ The Key Laboratory for Microbial Resources of the Ministry of Education, PR China, and Laboratory for Conservation and Utilization of Bio-Resources, Yunnan Institute of Microbiology, Yunnan University, Kunming, Yunnan 650091, PR China Chinese Academy of Sciences, Guangzhou 510301, PR China \\ ${ }^{2}$ Guangdong Key Laboratory of Marine Materia Medica, South China Sea Institute of Oceanology,
}

The genus Kineosporia was first described by Pagani \& Parenti (1978) and then amended by Itoh et al. (1989) on the basis of morphology and chemotaxonomy. Subsequently, Kudo et al. (1998) amended the compositions of the diaminopimelic acid isomers and whole-cell sugars of this genus. At the time of writing, there are six recognized species belonging to the genus Kineosporia, including the recently described organism Kineosporia babensis (Sakiyama et al., 2009). During an investigation into the diversity of endophytic actinomycetes from pharmaceutical plants, strain YIM $65293^{\mathrm{T}}$ was isolated from surface-sterilized stems of Tripterygium wilfordii, which is a member of the Celastraceae family of plants and known as lei gong teng in Chinese.

Samples of $T$. wilfordii were collected from Yunnan province, south-west China, and were surface-sterilized according to the method of Coombs \& Franco (2003). Strain YIM $65293^{\mathrm{T}}$ was isolated by using the procedure described by Li et al. (2009) and grown on tap water-yeast extract agar (Coombs \& Franco, 2003). The purified strain

Abbreviation: TBSA, tuberculostearic acid.

The GenBank/EMBL/DDBJ accession number for the 16S rRNA gene sequence of strain YIM $65293^{\top}$ is FJ214362.

Scanning electron micrographs of cells of strain YIM $65293^{\top}$ and a table showing the fatty acid contents of Kineosporia strains are available with the online version of this paper. was routinely cultivated on yeast extract-malt extract agar (ISP 2) at $28{ }^{\circ} \mathrm{C}$ and stored as an aqueous glycerol suspension $(20 \%, \mathrm{v} / \mathrm{v})$ at $-70{ }^{\circ} \mathrm{C}$.

The cultural characteristics of strain YIM $65293^{\mathrm{T}}$ were determined after 3 weeks incubation at $28{ }^{\circ} \mathrm{C}$, according to the methods of the International Streptomyces Project (ISP; Shirling \& Gottlieb, 1966). Czapek's agar, potato agar and nutrient agar were prepared as described by Waksman (1961). Colour determination was performed by comparison with chips from the Inter-Society Color Council - National Bureau of Standards colour charts (standard samples, no. 2106) (Kelly, 1964). After incubation on ISP 2 at $28{ }^{\circ} \mathrm{C}$ for 14 days, morphological properties were examined using a light microscope (BH-2; Olympus) and a scanning electron microscope (JSM-5600LV; JEOL).

For this study, the phenotypic characteristics of $K$. mikuniensis $\mathrm{NBRC} 16234^{\mathrm{T}}, K$. succinea $\mathrm{I}-273^{\mathrm{T}}, K$. aurantiaca JCM $3230^{\mathrm{T}}$, K. rhamnosa $\mathrm{I}-132^{\mathrm{T}}$ and K. rhizophila I- $449^{\mathrm{T}}$ as well as those of strain YIM $65293^{\mathrm{T}}$ were determined. Carbon source utilization was determined according to the methods of Shirling \& Gottlieb (1966) and Locci (1989). Acid production from carbohydrates was assessed as described by Gordon et al. (1974). Nitrogen source utilization was assessed according to Williams et al. (1989). Gelatin hydrolysis was determined by incubating strain YIM $65293^{\mathrm{T}}$ at $28{ }^{\circ} \mathrm{C}$ for 3 weeks on peptone-gelatin medium, comprising $\left(1^{-1}\right.$ distilled water) $5 \mathrm{~g}$ peptone and 
$120 \mathrm{~g}$ gelatin. Hydrolysis of urea was determined on peptone-glucose agar, comprising $\left(1^{-1}\right.$ distilled water) $1 \mathrm{~g}$ peptone, $1 \mathrm{~g}$ glucose, $5 \mathrm{~g} \mathrm{NaCl}$ and $2 \mathrm{~g} \mathrm{KH}_{2} \mathrm{PO}_{4}$, which was supplemented with $2 \%(\mathrm{w} / \mathrm{v})$ urea and $0.001 \%(\mathrm{w} / \mathrm{v})$ phenol red. Milk coagulation and peptonization were determined by using $20 \%$ (w/v) skimmed milk as the medium and incubation for 3 weeks at $28{ }^{\circ} \mathrm{C}$. Decomposition of other compounds was examined on the basal medium of Gordon et al. (1974). Growth at different temperatures $\left(4,10,15,20,28-37^{\circ} \mathrm{C}\right.$ at intervals of $1{ }^{\circ} \mathrm{C}, 45$, 55 and $\left.65{ }^{\circ} \mathrm{C}\right), \mathrm{pH}$ values $(\mathrm{pH} 4.0-10.0$, at intervals of 1.0 $\mathrm{pH}$ units) and $\mathrm{NaCl}$ concentrations $(1,3,5,7,10,12,15$ and $20 \%$; w/v) were determined on ISP 2 as the basal medium.

Biomass for chemotaxonomic analyses was obtained by growing the novel strain in tryptic soy broth (TSB) in shake flasks (at 180 r.p.m.) for $4-7$ days at $28{ }^{\circ} \mathrm{C}$. The analysis of cellular fatty acid composition followed the instructions of the Microbial Identification System (Sasser, 1990). The fatty acid compositions of $K$. mikuniensis NBRC $16234^{\mathrm{T}}, K$. succinea $\mathrm{I}-273^{\mathrm{T}}$ and $K$. rhizophila $\mathrm{I}-449^{\mathrm{T}}$ were determined as well that of strain YIM $65293^{\mathrm{T}}$. The purified cell-wall hydrolysate was prepared as described by Schleifer \& Kandler (1972). Amino acids in cell-wall hydrolysate were analysed by precolumn derivatization with $o$-phthalaldehyde by HPLC (Tang et al., 2009). Whole-cell hydrolysate sugars were determined using TLC as described by Staneck \& Roberts (1974). Phospholipids were extracted and identified according to published methods (Minnikin et al., 1979; Collins \& Jones, 1980). Menaquinones were extracted as described by Collins et al. (1977), and analysed by HPLC (Tamaoka et al., 1983). The G $+\mathrm{C}$ content of the genomic DNA was determined by the HPLC method according to Mesbah et al. (1989).

The 16S rRNA gene sequence of strain YIM $65293^{\mathrm{T}}$ was amplified by PCR and sequenced as described previously (Li et al., 2007). The resulting 16S rRNA gene sequence was compared with those of the type strains of the genus Kineosporia, which were retrieved from the GenBank database, and aligned using CLUSTAL_X (Thompson et al., 1997). Phylogenetic analysis was performed using MEGA version 4.0 (Tamura et al., 2007). Evolutionary distances and the $K_{\text {nuc }}$ value (Kimura, 1983) were calculated and clustering was performed with the neighbour-joining method (Saitou \& Nei, 1987). The topology of the phylogenetic tree was evaluated by the bootstrap resampling method of Felsenstein (1985) with 1000 replications.

Strain YIM $65293^{\mathrm{T}}$ grew well on ISP 2, ISP 3 , ISP 4, ISP 5 agars, potato agar and nutrient agar at $28{ }^{\circ} \mathrm{C}$. However, poor growth was observed on Czapek's agar. Strain YIM $65293^{\mathrm{T}}$ lacked aerial mycelium on any of the media tested. Colonies were moderate orange-yellow on ISP 2, ISP 4 and potato agars, orange-yellow on Czapek's agar, deep orange-yellow on ISP 5 agar and light orange on ISP 3 and nutrient agars. There was no diffusible pigment on any of the media tested. After incubation for nearly 1 week, the surfaces of the colonies became moist and glossy. Single spores, spherical to oval or pyriform, were borne at the tips of substrate hyphae (see Supplementary Fig. S1, available in IJSEM Online). Detailed physiological results are given in Table 1 and in the species description.

HPLC analysis of amino acids obtained from submerged cultures in shake flasks revealed that strain YIM $65293^{\mathrm{T}}$ contained Asp, Glu, Gly, Ala and Lys, but no diaminopimelic acid. Whole-cell hydrolysates contained glucose, galactose, mannose and ribose. The phospholipids comprised phosphatidylcholine, phosphatidylglycerol, phosphatidylinositol, diphosphatidylglycerol and phosphatidylinositol mannosides. The menaquinones were represented by MK- $9\left(\mathrm{H}_{4}\right)(94.8 \%)$ and MK-9 $\left(\mathrm{H}_{2}\right)(5.2 \%)$. Major fatty acids of the strain $(>10 \%)$ were $\mathrm{C}_{16: 0}(27.98 \%), \mathrm{C}_{18: 1}$ cis-9 $(20.67 \%)$ and tuberculostearic acid (TBSA, $\mathrm{C}_{18: 0}$ 10-methyl; $18.60 \%$ ). The detailed fatty acid profile is given in Supplementary Table S1 (in IJSEM Online). The $\mathrm{G}+\mathrm{C}$ content of the genomic DNA from strain YIM $65293^{\mathrm{T}}$ was $70.3 \mathrm{~mol} \%$.

The almost-complete 16S rRNA gene sequence (1425 bp) for strain YIM $65293^{\mathrm{T}}$ was determined. The results of the phylogenetic analysis indicated that strain YIM $65293^{\mathrm{T}}$ clustered with members of the genus Kineosporia (Fig. 1). The closest phylogenetic neighbour was Kineosporia mikuniensis NBRC $16234^{\mathrm{T}}$ ( $98.2 \%$ sequence similarity). Sequence similarities between strain YIM $65293^{\mathrm{T}}$ and other members of the genus Kineosporia were 97.0-98.1\%. Genomic relatedness between strain YIM $65293^{\mathrm{T}}$ and other members of the genus Kineosporia was examined according to the fluorometric micro-well method (Ezaki et al., 1989; He et al., 2005). The levels of DNA-DNA relatedness of strain YIM $65293^{\mathrm{T}}$ to K. mikuniensis NBRC $16234^{\mathrm{T}}$, K. succinea $\mathrm{I}-273^{\mathrm{T}}$, K. aurantiaca JCM $3230^{\mathrm{T}}$, K. rhamnosa $\mathrm{I}-132^{\mathrm{T}}$ and $K$. rhizophila $\mathrm{I}-449^{\mathrm{T}}$ were 59.0, 48.9, 48.1, 34.3 and $34.5 \%$, respectively. All of the DNA-DNA hybridization values were less than $70 \%$, the recommended threshold value for the delineation of genomic species (Stackebrandt \& Goebel, 1994), which supports the placement of strain YIM $65293^{\mathrm{T}}$ in a novel species of the genus Kineosporia.

Differences between strain YIM $65293^{\mathrm{T}}$ and other members of the genus Kineosporia were found for the reduction of nitrate, production of $\mathrm{H}_{2} \mathrm{~S}$, tolerance of $\mathrm{NaCl}$ concentration and utilization of sole carbon and nitrogen sources (Table 1). A striking difference was also observed in the composition of the diaminopimelic acid isomers. It was reported by Kudo et al. (1998) that strains in the genus Kineosporia showed variety in the ratio of diaminopimelic acid isomers and could be classified into LL type, meso type and LL-plus-meso type, and it has also been reported that the proportions of the two isomers in shake-flask cultures can vary with culture condition (Eke et al., 1989; Kudo et al., 1998). Nevertheless, this study detected no diaminopimelic acid isomers in submerged cultures of strain YIM $65293^{\mathrm{T}}$ in shake flasks. Strain YIM $65293^{\mathrm{T}}$ also had remarkable differences in the fatty acid profile, such as the quantitative differences in the proportions of $\mathrm{C}_{16: 0 \text {, }}$, $\mathrm{C}_{17: 0}, \mathrm{C}_{18: 1}$ cis-9 and TBSA. 
Table 1. Phenotypic characteristics that differentiate strain YIM $65293^{\top}$ from other species of the genus Kineosporia

Strains: 1, YIM $65293^{\mathrm{T}}$; 2, K. mikuniensis NBRC $16234^{\mathrm{T}}$; 3, K. succinea I- $273^{\mathrm{T}} ; 4$, K. aurantiaca JCM $3230^{\mathrm{T}} ; 5$, K. rhamnosa I-132 $2^{\mathrm{T}}$; 6, K. rhizophila $\mathrm{I}-449^{\mathrm{T}}$. Data were taken from this study. All strains were positive for hydrolysis of urea, starch and Tweens 20,40 and 80 and for utilization of L-arabinose, cellobiose, D-fructose, D-galactose, glucose, maltose, D-mannitol, L-rhamnose, turanose, glycine and L-valine. All strains were negative for decomposition of adenine, cellulose, gelatin, hypoxanthine, L-tyrosine and xanthine and for the utilization of sodium acetate and milk coagulation and peptonization. + , Positive; - , negative.

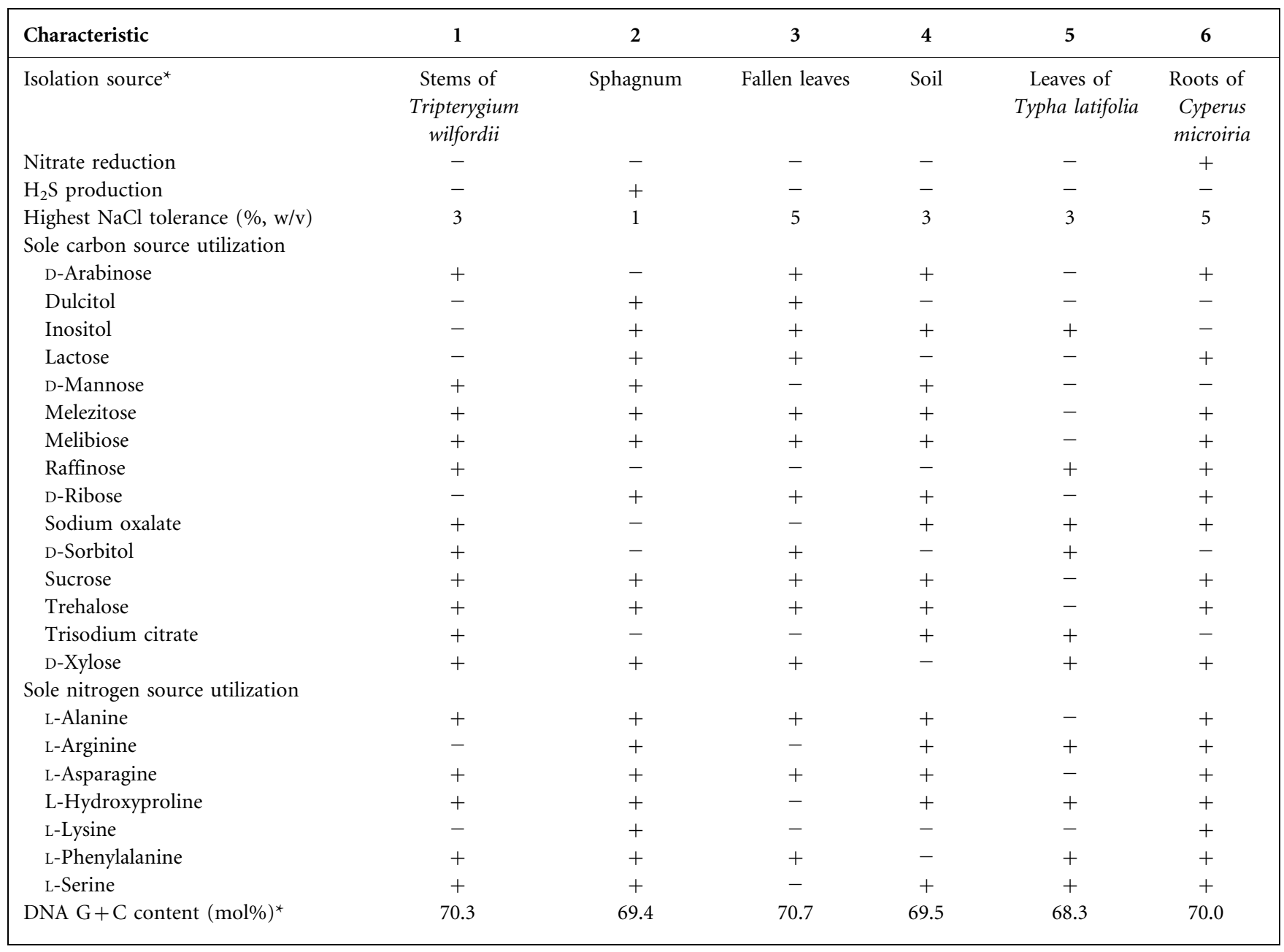

${ }^{\star}$ Data from Pagani \& Parenti (1978) and Kudo et al. (1998) except for strain YIM $65293^{\mathrm{T}}$.

On the basis of the phenotypic and phylogenetic studies, it is clear that strain YIM $65293^{\mathrm{T}}$ represents a novel species of the genus Kineosporia, for which the name Kineosporia mesophila sp. nov. is proposed.

\section{Description of Kineosporia mesophila sp. nov.}

Kineosporia mesophila (me.so'phi.la. Gr. adj. mesos medium; Gr. adj. philos loving; N.L. fem. adj. mesophila medium-temperature-loving, mesophilic).

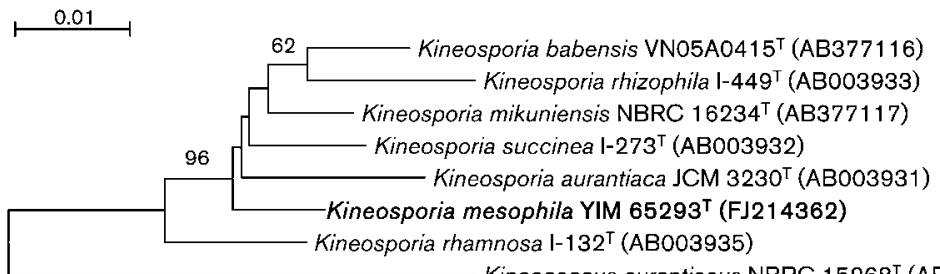

Kineococcus aurantiacus NBRC $15268^{\top}$ (AB007420)
Fig. 1. Neighbour-joining tree based on $16 \mathrm{~S}$ rRNA gene sequences showing the phylogenetic relationship between strain YIM $65293^{\top}$ and other members of the genus Kineosporia. Bootstrap values $(>50 \%)$ based on 1000 replications are shown at branch nodes. Bar, 1 substitution per 100 nucleotide positions. 
Substrate mycelia are light orange to deep orange-yellow. Does not produce any diffusible pigments on ISP 2, ISP 3, ISP 4, ISP 5 agars, potato agar, Czapek's agar or nutrient agar. Single spores, spherical to oval or pyriform, are borne at the tips of substrate hyphae. Growth occurs at $10-32{ }^{\circ} \mathrm{C}$ and $\mathrm{pH}$ 6.0-8.0. Tolerates $3 \%(\mathrm{w} / \mathrm{v}) \mathrm{NaCl}$. Negative for production of $\mathrm{H}_{2} \mathrm{~S}$, nitrate reduction and milk coagulation and peptonization. Urea, starch and Tweens 20,40 and 80 are hydrolysed. Adenine, cellulose, gelatin, hypoxanthine, L-tyrosine and xanthine are not decomposed. Utilizes Darabinose, D-fructose, glucose, D-xylose, maltose, D-mannitol, D-mannose, L-rhamnose, sodium oxalate, D-sorbitol and trisodium citrate as sole carbon sources, but not dulcitol, inositol, lactose, D-ribose or sodium acetate. Acid is produced from L-arabinose, cellobiose, D-galactose, melezitose, melibiose, raffinose, sucrose, trehalose and turanose. L-Alanine, L-asparagine, glycine, L-hydroxyproline, L-phenylalanine, L-serine and L-valine are used as sole nitrogen sources, but not L-arginine or L-lysine. The cellwall peptidoglycan contains aspartic acid, glutamic acid, glycine, alanine and lysine. Glucose, galactose, mannose and ribose are present in whole-cell hydrolysates. Phospholipids are phosphatidylcholine, phosphatidylglycerol, phosphatidylinositol, diphosphatidylglycerol and phosphatidylinositol mannosides. The predominant menaquinone is MK- $9\left(\mathrm{H}_{4}\right)$. Major fatty acids $(>10 \%)$ are $\mathrm{C}_{16: 0}$, $\mathrm{C}_{18: 1}$ cis-9 and TBSA.

The type strain, YIM $65293^{\mathrm{T}}\left(=\right.$ CCTCC AA $208061^{\mathrm{T}}=$ DSM $45271^{\mathrm{T}}$ ), was isolated from a surface-sterilized stem sample of Tripterygium wilfordii from Yunnan province, south-west China. The DNA $\mathrm{G}+\mathrm{C}$ content of the type strain is $70.3 \mathrm{~mol} \% .1$

\section{Acknowledgements}

This research was supported by the National Basic Research Program of China (No. 2010CB833800) and the Ministry of Science and Technology, P. R. China (2006DFA33550) and Yunnan Provincial Science and Technology Department (Nos 2009AC017, 2009DA002).

\section{References}

Collins, M. D. \& Jones, D. (1980). Lipids in the classification and identification of coryneform bacteria containing peptidoglycans based on 2,4-diaminobutyric acid. J Appl Bacteriol 48, 459-470.

Collins, M. D., Pirouz, T., Goodfellow, M. \& Minnikin, D. E. (1977). Distribution of menaquinones in actinomycetes and corynebacteria. J Gen Microbiol 100, 221-230.

Coombs, J. T. \& Franco, C. M. M. (2003). Isolation and identification of actinobacteria from surface-sterilized wheat roots. Appl Environ Microbiol 69, 5603-5608.

Eke, M. A., Alderson, G. \& Cross, T. (1989). An actinomycete that changes wall composition during sporulation. Lett Appl Microbiol $\mathbf{9}$, $1-4$.

Ezaki, T., Hashimoto, Y. \& Yabuuchi, E. (1989). Fluorometric deoxyribonucleic acid-deoxyribonucleic acid hybridization in microdilution wells as an alternative to membrane filter hybridization in which radioisotopes are used to determine genetic relatedness among bacterial strains. Int J Syst Bacteriol 39, 224-229.

Felsenstein, J. (1985). Confidence limits on phylogenies: an approach using the bootstrap. Evolution 39, 783-791.

Gordon, R. E., Barnett, D. A., Handerhan, J. E. \& Pang, C. H.-N. (1974). Nocardia coeliaca, Nocardia autotrophica, and the nocardin strain. Int J Syst Bacteriol 24, 54-63.

He, L., Li, W., Huang, Y., Wang, L. M., Liu, Z. H., Lanoot, B. J., Vancanneyt, M. \& Swings, J. (2005). Streptomyces jietaisiensis sp. nov., isolated from soil in northern China. Int J Syst Evol Microbiol 55, 1939-1944.

Itoh, T., Kudo, T., Parenti, F. \& Seino, A. (1989). Amended description of the genus Kineosporia, based on chemotaxonomic and morphological studies. Int J Syst Bacteriol 39, 168-173.

Kelly, K. L. (1964). Inter-Society Color Council - National Bureau of Standards Color Name Charts Illustrated with Centroid Colors. Washington, DC: US Government Printing Office.

Kimura, M. (1983). The Neutral Theory of Molecular Evolution. Cambridge: Cambridge University Press.

Kudo, T., Matsushima, K., Itoh, T., Sasaki, J. \& Suzuki, K. (1998). Description of four new species of the genus Kineosporia: Kineosporia succinea sp. nov., Kineosporia rhizophila sp. nov., Kineosporia mikuniensis sp. nov. and Kineosporia rhamnosa sp. nov., isolated from plant samples, and amended description of the genus Kineosporia. Int J Syst Bacteriol 48, 1245-1255.

Li, W. J., Xu, P., Schumann, P., Zhang, Y. Q., Pukall, R., Xu, L. H., Stackebrandt, E. \& Jiang, C. L. (2007). Georgenia ruanii sp. nov., a novel actinobacterium isolated from forest soil in Yunnan (China) and emended description of the genus Georgenia. Int J Syst Evol Microbiol 57, 1424-1428.

Li, J., Zhao, G. Z., Qin, S., Zhu, W. Y., Xu, L. H. \& Li, W. J. (2009). Streptomyces sedi sp. nov., isolated from a surface-sterilized tissue of Sedum sp. Int J Syst Evol Microbiol 59, 1492-1496.

Locci, R. (1989). Streptomyces and related genera. In Bergey's Manual of Systematic Bacteriology, vol. 4, pp. 2451-2508. Edited by S. T. Williams, M. E. Sharpe \& J. G. Holt. Baltimore: Williams \& Wilkins.

Mesbah, M., Premachandran, U. \& Whitman, W. B. (1989). Precise measurement of the $\mathrm{G}+\mathrm{C}$ content of deoxyribonucleic acid by highperformance liquid chromatography. Int J Syst Bacteriol 39, 159-167.

Minnikin, D. E., Collins, M. D. \& Goodfellow, M. (1979). Fatty acid and polar lipid composition in the classification of Cellulomonas, Oerskovia and related taxa. J Appl Bacteriol 47, 87-95.

Pagani, H. \& Parenti, F. (1978). Kineosporia, a new genus of the order Actinomycetales. Int J Syst Bacteriol 28, 401-406.

Saitou, N. \& Nei, M. (1987). The neighbor-joining method: a new method for reconstructing phylogenetic trees. Mol Biol Evol 4, 406-425.

Sakiyama, Y., Thao, N. K. N., Giang, N. M., Miyadoh, S., Hop, D. V. \& Andp, K. (2009). Kineosporia babensis sp. nov., isolated from plant litter in Vietnam. Int J Syst Evol Microbiol 59, 550-554.

Sasser, M. (1990). Identification of bacteria by gas chromatography of cellular fatty acids. USFCC Newsl 20, 16.

Schleifer, K. H. \& Kandler, O. (1972). Peptidoglycan types of bacterial cell walls and their taxonomic implications. Bacteriol Rev 36, 407-477.

Shirling, E. B. \& Gottlieb, D. (1966). Methods for characterization of Streptomyces species. Int J Syst Bacteriol 16, 313-340.

Stackebrandt, E. \& Goebel, B. M. (1994). Taxonomic note: a place for DNA-DNA reassociation and $16 \mathrm{~S}$ rRNA sequence analysis in the present species definition in bacteriology. Int J Syst Bacteriol 44, 846-849.

Staneck, J. L. \& Roberts, G. D. (1974). Simplified approach to identification of aerobic actinomycetes by thin layer chromatography. Appl Microbiol 28, 226-231. 
Tamaoka, J., Katayama-Fujimura, Y. \& Kuraishi, H. (1983). Analysis of bacterial menaquinone mixtures by high performance liquid chromatography. J Appl Bacteriol 54, 31-36.

Tamura, K., Dudley, J., Nei, M. \& Kumar, S. (2007). MEGA4: Molecular evolutionary genetics analysis (MEGA) software version 4.0. Mol Biol Evol 24, 1596-1599.

Tang, S. K., Wang, Y., Lou, K., Mao, P. H., Xu, L. H., Jiang, C. L., Kim, C. J. \& Li, W. J. (2009). Kocuria halotolerans sp. nov., a novel actinobacterium isolated from a saline soil in China. Int J Syst Evol Microbiol 59, 1316-1320.
Thompson, J. D., Gibson, T. J., Plewniak, F., Jeanmougin, F. \& Higgins, D. G. (1997). The CLUSTAL_X windows interface: flexible strategies for multiple sequence alignment aided by quality analysis tools. Nucleic Acids Res 25, 4876-4882.

Waksman, S. A. (1961). The Actinomycetes, vol. 2. Baltimore: Williams \& Wilkins.

Williams, S. T., Goodfellow, M. \& Alderson, G. (1989). Genus Streptomyces Waksman and Henrici 1943, 339 ${ }^{\mathrm{AL}}$. In Bergey's Manual of Systematic Bacteriology, vol. 4, pp. 2452-2492. Edited by S. T. Williams, M. E. Sharpe \& J. G. Holt. Baltimore: Williams \& Wilkins. 